\title{
Bacteriological and molecular studies on Salmonella in chickens
}

\author{
Hamza M. I. Eid ${ }^{a}$, Dalia Mansour $\mathbf{H}^{\mathrm{b}}$. and Dina E. F. Elsayed \\ Bacteriology, Immunology and Mycology Department ${ }^{a}$, Avian and Rabbit \\ Med. Department. Faculty of Veterinary Medicine, Suez Canal University
}

\begin{abstract}
A total 396 samples from 132 broiler showed diarrhea and common clinical signs (samples from liver, heart blood and intestinal content) were collected from Port Said governorate. All samples were subjected for isolation and identification of salmonella. Salmonella species were recovered in $121(30.5 \%)$ from all examined samples according to the traditional methods . 25 samples from broiler chicken which showed typical post mortem picture for salmonella infection and confirmed by biochemically traditional methods were subjected to API 20E system for qualification that rapid test. Serotyping of Salmonella isolates could be identified into Salmonella enteritidis(1,9,12;g,m;-), Salmonella kentuckey (8,20;I;z6), Salmonella bloemfontein (6,7;e,n,x,z42) and Salmonella archavalenta (4,(15),12,a;1,7).

The result of sensitivity of the four Salmonella strains to 13 antimicrobial agents revealed that Salmonella isolates were sensitive to choloramphenicol, gentamycin, ofloxacin variable to ampicillin, enrofloxacin, naldixic acid, sulfa/trimethoprim and resistant to erythromycin and lincomycin.

Theses identified Serotyping of Salmonella were further confirmed using polymerase chain reaction technique and SYBR Green realtime PCR for detection of Salmonella invA gene that present only in Salmonella species as a rapid and more sensitive technique. SYBR Green real-time PCR was conducted to the four identified Salmonella serovars to detect the difference in melting temperature. It showed that S.enteitidis Time Product1 (-R'(T) at 82, S. bloemfontein at 77.63, Salmonella kentucky at 83.51 and Salmonella arechavaleta at 81.92 .
\end{abstract}

Key Word: Salmonella; API; invA gene; SYBR Green; antimicrobial drug

\section{Introduction}

Salmonella remains one of the leading causes of human foodborne disease outbreaks, and is usually associated with the consumption of poultry products (Alcaine et al, 2007; Scallan et al, 2011and Fernandez et al, 2012), This 
organism cause substantial economic loss resulting from mortality, morbidity, and poor growth of infected animals, poultry and couse serious problem for the food industry (Banavandi et al, 2005). Conventional procedures used to identify Salmonella are time-consuming, labor intensive and requires high quality of biochemical materials (McQuiston et al., 2004; Gallegos-Robles et al., 2008). Amplification of invA gene of Salmonella has been reported as a suitable target for PCR amplification, with potential diagnostic applications ( $\boldsymbol{L i}$ et $\boldsymbol{a l}$, 2013).

API 20E and invA PCR for the identification of Salmonella enterica were clarified by Nucera et al (2006). Sybr Green Real -Time PCR is a useful tool when a large number of samples have to be analyzed because it is less expensive (De Medici et al, 2003; Elizaquivel and Aznar, 2008; Fenicia et al, 2007 and Fricker et al, 2007).

\section{Material and Methods}

Three hundred and ninety six samples of clinically diseased broiler showing diarrhea(132 each of liver, heart blood and intestinal content) were collected from Port Said governorate

Media used for isolation of Salmonella species: Enrichment medium, Rappaport vassiliadis R10 broth (Difco) and Selenite F. broth
(Difco), Selective and differential plating solid media MacConkey agar ( Biolife), XLD (Toply House), and Salmonella Shigella agar S.S (Oxoid) (Cruichshank et al, 1982). Media used for biochemical identification, preservation and detection of Motility: Triple sugar iron agar. (Toply House), Simmon's citrate agar. (Oxoid), Christensen' urea agar base. (Oxoid) and Semisolid nutrient agar $0.4 \%$ (Cruichshank et al, 1982)

Media for antibiotic sensitivity test: Muller Hinton agar (Difco). Antibiotic discs were obtained from (Oxoid),According to WHO

Reagents and Solutions for biochemical tests according to Cruickshank et al (1982). API®20E (bioMérieux® SA, 692080 Marcy r E toile, France, Lot. 1002016630)

Diagnostic Salmonella antisera: Polyvalent and monovalent Salmonella antisera (denka company of antisera) were kindly supplied from Animal Health Research institute, Doki, Giza .According to $\mathrm{K}-$ White scheme (Kauffman, 1974) as described by Edwads and Ewing (1972) to determine the "O" and "H" antigen . Reagents and media used for invA gene PCR detection according to Sambrook et al (1989).

Oligonucleotide primers used in cPCR. Two pairs of primers were supplied from metabion (Germany). 
They have specific sequence and amplify specific products.

DNA Molecular weight marker: Gel Pilot 100 bp ladder (cat. no. 239035) supplied from QIAGEN. Number of bands: 6, Size range: 100-600 bp.

Detection of invA gene: according to Sambrook et al (1989), Cycling conditions of the primers during al (1999).

\begin{tabular}{|c|c|c|c|c|}
\hline Primer & $\begin{array}{l}\text { Target } \\
\text { gene }\end{array}$ & $\begin{array}{l}\text { Primer sequence } \\
\qquad\left(5^{\prime}-3^{\prime}\right)\end{array}$ & $\begin{array}{c}\text { Length of } \\
\text { amplified } \\
\text { product }\end{array}$ & Reference \\
\hline 139 & \multirow{2}{*}{ invA } & GTGAAATTATCGCCACGTTCGGGCAA & \multirow{2}{*}{$284 \mathrm{bp}$} & \multirow{2}{*}{$\begin{array}{c}\text { Oliveira } e t \\
a l ., 2003\end{array}$} \\
\hline 141 & & TCATCGCACCGTCAAAGGAACC & & \\
\hline
\end{tabular}

\begin{tabular}{|c|c|c|c|c|c|}
\hline Agent & Primer & $\begin{array}{l}\text { Target } \\
\text { gene }\end{array}$ & $\begin{array}{c}\text { Primer sequence } \\
\left(5^{\prime}-3^{\prime}\right)\end{array}$ & $\begin{array}{c}\text { Length } \\
\text { of } \\
\text { amplified } \\
\text { product }\end{array}$ & Reference \\
\hline \multirow{2}{*}{ S.Kentucky } & fli 15 & \multirow{2}{*}{ fliC } & CGGTGTTGCCCAGGTTGGTAAT & \multirow{2}{*}{$559 \mathrm{bp}$} & \multirow{2}{*}{$\begin{array}{c}\text { Soumet et } \\
\text { al., } 1999\end{array}$} \\
\hline & Tym & & ACTCTTGCTGGCGGTGCGACTT & & \\
\hline \multirow{2}{*}{ S.enteritidis } & SEFA2 & \multirow{2}{*}{ sefA } & GCAGCGGTTACTATTGCAGC & \multirow{2}{*}{$310 \mathrm{bp}$} & \multirow{2}{*}{$\begin{array}{l}\text { Akbarmehr } \\
\text { et al., } 2010\end{array}$} \\
\hline & SEFA4 & & TGTGACAGGGACATTTAGCG & & \\
\hline
\end{tabular}

\section{$\underline{\text { Results }}$}

121positive sample out of $396(30.5 \%)$ from clinically diseased birds showed diarrhea, clinical signs and postmortem lesions suspect salmonella infection. 25 samples obtained from heart blood collected from broiler which have typical post mortem picture and identified by traditional methods confirmed by biochemical tests were subjected to API 20E test for comparing the results with the traditional one 21out of 25 samples with percentage $84 \%$ were belong to Salmonella spp.
cPCR according to (Oliveira et al, 2003). Detection of S.enteritidis using SYBR Green real-time PCR: according to Akbarmehr et al, 2010. Cycling conditions for SYBR Green real time PCR of $S$. Kentucky according to Quantitect SYBR Green PCR kit and Soumet et 
to Ampicillin, Chloramphenicol, Enrofloxacin, Gentamycin, Naldixic acid, Neomycin, Tetracyclin, Sulfa/trimethoprim, Ciprofloxacin and Ofloxacin ,while Salmonella Kentucky were highly sensitive for Chloramphenicol and Gentamycin only. The antibiogram of Salmonella Bloemfontein were highly sensitive Ampicillin, Chloramphenicol, Enrofloxacin, Gentamycin, Naldixic acid,Tetracyclin,

Sulfa/trimethoprim, Ciprofloxacin, Ofloxacin and cephhadrine while Salmonella arechavaleta were sensitive to Ofloxacin and cephhadrine. A PCR assay targeting invA gene of Salmonella was standardized for rapid detection and confirmation of Salmonella isolates. The assay relied on specific amplification of a $284 \mathrm{bp}$ product In the SYBR Green I real-time PCR, the amplification of the DNA target is measured in terms of the increment in the quantity of fluorescence determined at the end of each amplification cycle. In brief, SYBR Green I binds to the minor groove of dsDNA, greatly enhancing the fluorescence. The results of SYBR Green real time PCR were detected the difference of the four identified Salmonella strains in the time product.

The result of SYBR Green of Salmonella enteritidis and Salmonella Bloemfontein, kentucky and Salmonella arechavaleta

Table ( 1 ): Serological identification of the four suspected Salmonella isolates

\begin{tabular}{|c|c|c|c|}
\hline \multirow{2}{*}{ Serotype } & $\begin{array}{c}\text { Somatic antigen } \\
(\mathbf{O})\end{array}$ & \multicolumn{2}{|c|}{ Flagella (H) antigens } \\
\cline { 3 - 4 } & $1,9,12$ & Phase 1 & Phase 2 \\
\hline S. enteritidis & 8,20 & $\mathrm{~g}, \mathrm{~m}$ & - \\
S. kentuckey & 6,7 & $\mathrm{I}$ & $\mathrm{z} 6$ \\
S. eloemfontein & $4, \mathrm{n}, \mathrm{x}$ & $\mathrm{z} 42$ \\
S. archavalenta & $4,(5), 12$ & $\mathrm{a}$ & 1,7 \\
\hline
\end{tabular}

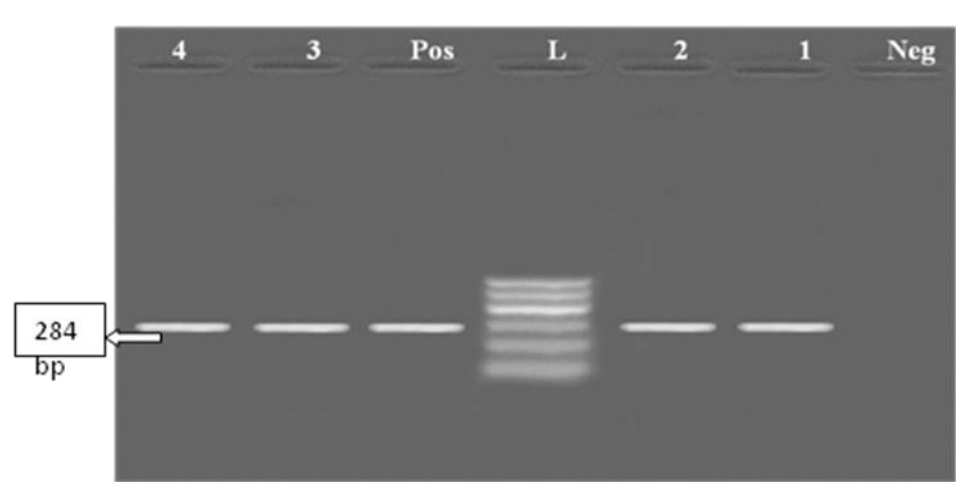

Photo(1): Electrophoresis of invA gene in the four isolates by PCR products on $1.5 \%$ agarose 
Table (2): The time product after using SYBR Green dye on Salmonella enteritidis, Salmonella Bloemfontein, Salmonella kentucky and Salmonella arechavaleta

\begin{tabular}{|c|c|c|}
\hline Well name & Dye & Tm Product1 (-R'(T)) \\
\hline Negative(S. bloemfontein) & SYBR & 77.63 \\
\hline S.enteitidis & SYBR & 82.00 \\
\hline Pos. S. enteitidis & SYBR & 82.53 \\
\hline Negative(S. arechavaleta) & SYBR & 81.92 \\
\hline S. kentucky & SYBR & 83.51 \\
\hline Pos. S. Kentucky & SYBR & 83.51 \\
\hline
\end{tabular}
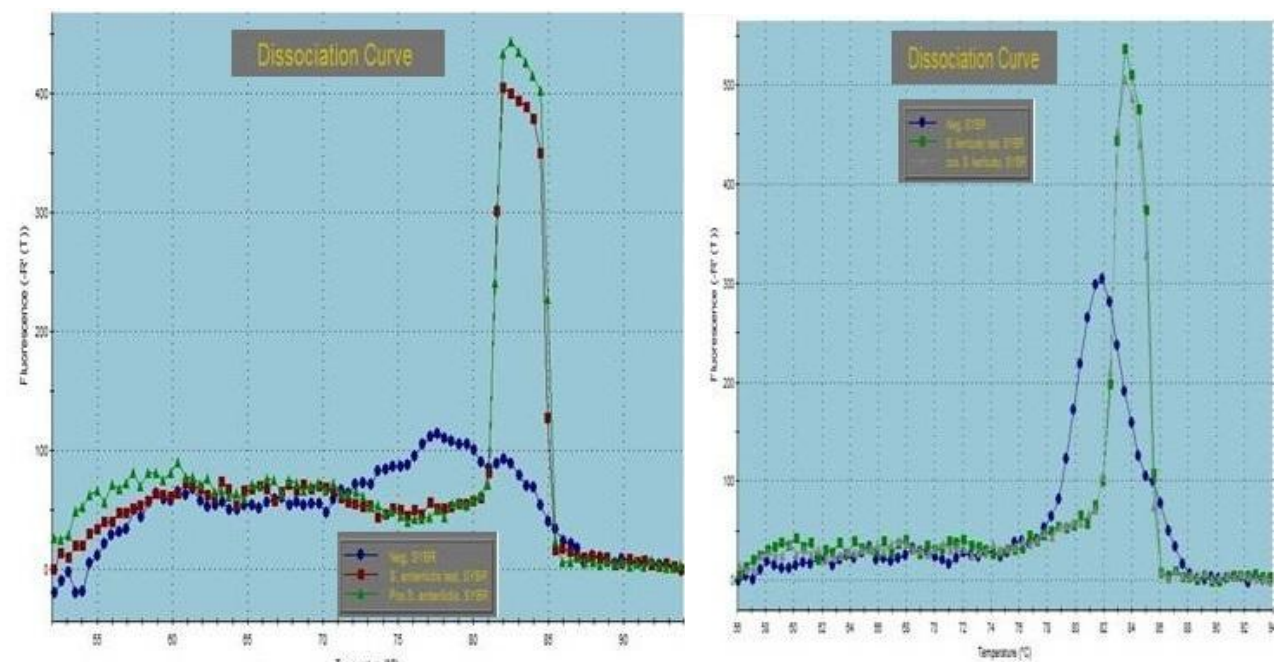

Photo (2): Time product using SYBR Green dye on Salmonella enteritidis, Salmonella Bloemfontein, Salmonella kentucky and Salmonella arechavaleta

\section{Discussion}

Salmonella causes a serious health problem in developing countries through a wide range of human diseases such as enteric fever, gastroenteritis and bacteremia (Banavandi et al, 2005). The majority of human Salmonellosis cases are caused by the consumption of contaminated poultry products (Geimba et al, 2004). All samples collected from suspected birds showed symptoms were similar to those described by (Gast, 2003). Gross lesions were similar to that reported by (Gast, 2003). For the isolation of Salmonellae, enrichment was necessary which done using Rappaport- vassiliadis, same results were detected by (Iwade et al, 2006). All samples were firstly inoculated into Rappaport vassiliadis $t$ broth, (which enriched small number of Salmonella in contaminated samples) and 
incubated for 24 hours, before plating on solid media; as these enrichments and plating media have been successfully used by Harvey and Price (1975) and Nassib et al (2003). Similar colonial appearance was reported by and Cruickshank et al (1982) and Gast et al (2004).

Incidence of Salmonella isolation from organ samples were $30.5 \%$ from heart blood, liver and caecal content that collected from 132 broiler chickens. Suspected isolates were confirmed biochemically according to (Cruickshank et

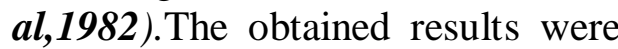
in agreement with (Bailey et al, 2005 ) who reported that Salmonella positive samples ranged from $8 \%$ to $34 \%$ due to wide spread of Salmonella. This higher incidence suggesting that Salmonella spp. indicating wide spread and potential hazard of interspecies sharing of this organism and require more epidemiological survey.

Salmonella was localized with highest incidence in intestine and caecal content then followed by liver and heart as Salmonella passed from digestive tract firstly then followed by parenchymatous organs these results were in agreement with data reported by Berthelot-Herault et al (2003).

The present study showed that isolation Salmonella according to the reading of API 20E system were $84 \%$ (21 out of 25). These percentages were closer to Saeed et al (2011) but in disagreement with Nucera et al (2006), this may be attributed to the difference in sampling procedure. Serological tests should be conducted to confirm biochemical testing. Serological and molecular test can be applied on the pure culture to provide a definitive confirmation of the isolated strains. Salmonellae possess antigens designated somatic $(\mathrm{O})$ and flagella $(\mathrm{H})$ which may be identified by specific typing sera, and the serovar may be determined by reference to the antigenic formulae in the Kauffman-White scheme .Our results of serological identification agreed with Brenner et al (2000). The isolates confirmed and serotyped as S.enteritidis, S.kentucky, S.bloemfontein and S.arechavaleta. As illustrated in table( 1 ),the antigenic formula of Salmonella enteritidis was $(\mathrm{O} 1,9,12 ; \mathrm{g}, \mathrm{m} ;-)$, Salmonella kentuckey(O8,20;I,z6), Salmonella bloemfontein $(\mathrm{O} 6,7$; b; $\mathrm{e}, \mathrm{n}, \mathrm{x} ; \mathrm{z} 42$ ) and Salmonella arechavaleta $(\mathrm{O} 4,(5), 12 ; \mathrm{a} ; 1,7)$. These results were agreed with Grimont et al (2007) S. bloemfontein and $S$. arechavaleta were isolated for the first time in Egypt.

Concerning sensitivity to antibiotics the isolated 4 strains were examined against 13 antibiotic discs. The MICs (Minimum Inhibitory Concentrations) data demonstrated very high level of resistance to erythromycin and 
lincomycin. Previous studies on $S$. enteritidis, isolated from poultry had also demonstrated $100 \%$ resistance to erythromycin and lincomycin. The development and spread of antimicrobial resistance to erythromycin and lincomycin may be linked to selection pressure caused by excessive use of this drug. Salmonella resistance at varying concentrations of erythromycin has also been reported by Sultana et al (1995). The higher resistance rates of $S$. enteritidis to erythromycin and lincomycin suggest limiting use of therapeutic potentials of these antimicrobial agents. From the antibiogram for the four strains our study showed that were resistant to erythromycin and lincomycin antimicrobial agents this were in agreement with Randa et al (2006).

Antimicrobial resistance in Salmonella strains is generally encoded by plasmid, which has been acquired as consequence of antibiotic pressure in humans and veterinary medicine; however, due to the fluidity of resistant plasmids and transposes, antimicrobial drug resistance pattern cannot be recorded as satisfactory method for discriminations within serovars (Olsen etal., 1992). An inevitable side effect of antibiotic use, which was associated to the adaptability of bacteria and microbial genome evolution, was the emergence and dissemination of resistant bacteria. Resistant commensally bacteria of food animals might contaminate, like S. enteritidis (zoonotic bacteria), poultry products, thus reaching the intestinal tract of humans along with contaminated food. Antimicrobial resistance can involve not just obvious pathogens but also commensal bacteria, which may act as an enormous reservoir of antimicrobial resistance genes. Thus, antimicrobial use in medicine and agriculture affects the general ecology of bacterial communities, including interactions between bacteria and their environment but also mechanisms by which antimicrobial resistance genes spread and persist. Their use, especially in food animals, can also have adverse effects on human health (O,Brien, 2002). Resistance can be caused by a large number of mechanisms, involving decreased antibiotic accumulation, physical modification or destruction of the antibiotics, and alteration of the enzyme target of antibiotic action. Recently, a mechanism of resistance involving the active efflux of antibiotics by multidrug efflux pumps was also elucidated (Soto et al, 2003).

In contrast to traditional methods, the use of PCR is one of the most sensitive, specific and rapid tests through rapid detection for invA gene which is specific for genus Salmonella. PCR-based techniques can be applied to detect culturable and non-culturable Salmonella in samples within hours Instead of days required in conventional biochemical assays (Abd $\boldsymbol{E l}$ - 
Haleem et al, 2003). So, at the next step, PCR technique was used to confirm the previous results. In this work molecular genetics study has been carried out to identify the genetic character of Salmonella by using invA gene specific PCR (White et al, 2002) .

A PCR assay targeting invA gene of Salmonella was standardized for rapid detection and confirmation of Salmonella isolates. The assay relied on specific amplification of a 284 bp product as shown in photo (1). All the biochemically confirmed isolates of Salmonella were tested for amplification of invA gene by PCR, the results agreed with Kaushik et al (2014) who reported that Salmonella positive by predicted a 284 bp DNA fragment when all strains were subjected to Salmonella- specific gene (inv A).

The SYBR ${ }^{\circledR}$ Green chemistry was preferred to the commonly used TaqMan ${ }^{\circledR}$ chemistry since SYBR ${ }^{\circledR}$ Green assays present the advantage of allowing the use of only two primers in the conserved region surrounding the more polymorphic sequence. In addition, SYBR® Green assays are cheaper and permit post-amplification verification through specificity by melting temperature analysis (Postollec et al, 2011).

The SYBR ${ }^{\circledR}$ Green qPCR assays for Salmonella detection developed and validated in this paper could be combined with the four assays for
Salmonella detection previously described by Barbau-Piednoir et al ( 2013) and run all together on a single plate. Since this approach is modular, detection assays can be added to detect a wider range of foodborne pathogens or emerging pathogens. The only requirement is to develop an assay able to be run with the same conditions, allowing its use in high throughput on the same 96-well plate.

Table (2) \&photo (2) clarified that isolated S.enteitidis test was confirmed by SYBR Green real time PCR showed that Tm Product1 (-R'(T) at temperature 82 compared to control positive (Salmonella enteitidis) at 82.51 and negative with S. Bloemfontein at 77.63. S.kentuckey was confirmed by SYBR Green real time PCR Tm Product1 $\left(-\mathrm{R}^{\prime}(\mathrm{T})\right.$ at temperature at 83.51 compared to control positive Salmonella kentucky at 83.51 and negative Salmonella arechavaleta at 81.92 .

From this study we conclude that Salmonella are the main cause of economic losses resulting from mortality, morbidity, and poor growth of infected birds, Also, considered one of human food borne disease outbreaks. so, the detection and eradication of Salmonella from poultry farms is of primary importance. Also the traditional methods for identification of Salmonella were more accurate than API 20E system, but were time-consuming, 
labor intensive and require high quality of biochemical materials. Detection of Salmonella invA gene that present only in Salmonella species is one of the most sensitive, specific and rapid tests. Such data is essential for developing appropriate treatment of salmonellosis. Periodical microbiological examination against Salmonella species in broilers must be done. The need for continued surveillance emphasized to determine local antimicrobial susceptibility data to identify changing pattern of resistance to avoid miss-use of antibiotic and resistant strains against the antimicrobial agents.

\section{References}

Abd-El-Haleem, D; Kheiralla, Z; Zaki, S; Rushedy, A; Abd-ElRahiem, W (2003):Multiplex-PCR and PCR-RFLP assays to monitor water quality against pathogenic bacteria. J Environ Monit 5: 865870.

Akbarmehr, J.; Salehi; T.Z. and Brujeni, G.H. N. (2010): Identification of Salmonella isolated from poultry by MPCR technique and evaluation of their hsp groEL gene diversity based on the PCRRFLP analysis.African Journal of Microbiology Research. Vol.4(15), pp. 1594-1598, August 2010.

Alcaine, S. ; Sukhnanand, S.; Warnick, L. D.; Su, W.;McGann, P.; McDonough, P. and Wiedmann, M. (2005): Ceftiofurresistant Salmonella strains isolated from dairy farms represent multiple widely distributed subtypes that evolved by independent horizontal gene transfer. Antimicrob. Agents Chemother. 49, (10) : 4061-7.

Bailey, J.; N.; Cox, D.; Cospy and L.; Richardson (2005): Movement and persistence of Salmonella in broiler chickens following oral or intracloacal inoculation. J. Food Prot., 86:2698-2701.

Banavandi, M.; Shahhosseiny, M.; Shahbazzadeh, D.; Karimi, ; irzahoseini, H.; Mahboudi, F.; Abachi, M.; Javadi, G. (2005). Selective Amplification of prt, tyv and invA Genes by Multiplex PCR for Rapid Detection of Salmonella typhi . Iran Biomed 9: 135-138.

Barbau-Piednoir E.; BotteldoornN,Y. M.; Mahillon J.; Roosens, N.H. (2013):

Development and validation of qualitative SYBR $®$ Green real-time PCR for detection and discrimination of Listeria spp. and Listeria monocytogenes. Appl Microbiol Biotechnol 97(9):40214037.

Berthelot - Herault, F.; Mompart, F.; Zygmunt, S.; Dubray, G. and DuchetSuchaux, M. (2003): Antibody responses in the serum and gut of chicken lines differing in cecal carriage of Salmonella enteritidis, Veterinary Immunology and Immunopathology, 96, 43-52.

Brenner, F.; Villar, R.; Angulo, F.; Tauxe, R. \& Swaminathan, B. (2000): Salmonella nomenclature. Journal of Clinical Microbiology, 38:2465- 2467. 
Center for Health Protection, Department of Health Hong Kong.: Scientific Committee on Enteric infections and Foodborne Diseases, Center for Health Protection.

Cruickshank, R.; Duguid, J. and Swain, R. (1982): Medical microbiology; 1070 pp. E. and S. Livingstone Lim., Edin-burgh and London.

De Medici, D.; Croci, L.; Delibato, E; Di Pasquale, S.; Filetici, E.; and Toti, L. (2003): Evaluation of DNA extraction methods for use in combination with SYBR Green I real-time pcr to detect Salmonella enterica serotype enteritidis in poultry. Applied \& Environmental Microbiology, 69: 3456-3461.

Edward, P. and Ewing, W. (1972): Identification of enterobacteriaceae. 3rd Ed., Burgeon Publishing Compang, Minneapolis Atlanta, U. S. A. 208 337.

Elizaquivel P.; Aznar R. (2008): A multiplex RTi-PCR reaction for simultaneous detection of Escherichia coli O157:H7, Salmonella spp. and Staphylococcus aureus on fresh, minimally processed vegetables. Food Microbiol. 25, 705-713.

Fenicia L.; Anniballi F.; De Medici, D.; Delibato, E.; Aureli P. (2007): SYBR Green real-time PCR method to detect Clostridium botulinum type A. Appl. Environ. Microbiol. 73, 2891-2896.
Fernandez, A.; Calleja, A.; Fernandez, G. and Capita, R. (2012): Prevalence and antimicrobial resistant of Salmonella serotypes isolated from poultry in Spain: comparison between 1993 and 2006. Int J Food Microbiol., 153: 281-287.

Fricker M.; Messelhausser, U.; Busch U.; Scherer, S.; EhlingSchulzm. (2007). Diagnostic realtime PCR assays for the detection of emetic Bacillus cereus strains in foods and recent food-borne outbreaks. Appl. Environ. Microbiol. 73, 1892-1898.

Gallegos-Robles, M.; MoralesLoredo, A.; Alvarez-Ojeda, G.; Vega, P.; Chew, M. Y.; Velarde, S.; Fratamico P (2008) Identification of Salmonella serotypes isolated from cantaloupe and chile pepper production systems in mexico bypcrrestriction fragment length polymorphism. J Food Prot 71:2217-2222.

Gast, R. (2003): Paratyphoid Infections. In Saif, Y.M., Diseases of Poultry 11th Ed. (pp. 583-599). Iowa State Press, Iowa.

Gast, R., Mitchell and Holt, P. (2004): Evaluation of culture media for detecting air-borne Salmonella enteritidis from the environmentally infected laying hens. Journal of Poultry Science, 83:1106-1011.

Geimba, M.; Tondo, E.; Oliveira, F.; Canal, C. (2004): Serological characterization and prevalence of spvR genes in Salmonella isolated 
from foods involved in outbreaks in Brazil. J Food Protect 67: 12291233.

Grimont, P.A.D.; Grimont, F. and Bouvet, P. (2000): Taxonomy of the Genus Salmonella. In: Wray, C., and A. Wray (eds); Salmonella in Domestic Animals. CABI Publishing, Wallingford, UK, 1-17.

Harvey, R. and T. Price. (1975): Studies on the isolation of Salmonella Spp. Journal of Hygiene, 74: 369-374.

Iwade, Y. K.; Tamura, A.; Yamauchi, N. H.; Kumazawa, Y. and Sugiyama, A.; (2006): Characterization of the outbreakderived Salmonella enterica serovar enteritidis strains with atypical triple sugar iron and Simmon's citrate Reactions. Japanese Journal of Infectious Diseases, 59: 512-513. Kauffman, G. (1974): Kauffman White Scheme. WHO. Pd 172, 1, rev. 1 Acta. Bath. Microb. Sc. 61:385.

Kaushik, P.; Anjay,M.; Kumari, S.; Bharti, S.K. and Dayal S. (2014): Isolation and prevalence of Salmonella from chicken meat and cattle milk collected from local markets of Patna, India, Veterinary World 7(2): 62-65.

Li, R.; Wang, Y.; Shen, J. and Wu, C. (2013): Development of a novel hexa-plex PCR method for identification and serotyping of Salmonella species. Foodborne Patho. Dis., 11: 75-77.

McQuiston, J.R.; Parrenas, R.; Ortiz-Rivera, M., Gheesling, L.; Brenner, F.; Fields, P.I. (2004)
Sequencing and comparative analysis of flagellin genes flic, fljb, and flpa from Salmonella. J Clin Microbiol 42:1923-1932.

Nassib, T. A.; El-Din, M. Z. and El-Sharoud, W. M.; (2003): Assessment of the presence of Salmonella spp. in Egyptian dairy products using various detection media. Journal of Applied Microbiology, 37: 405.

Nucera, D. M.; Maddox, C. W.; Hoien-Dalen, P. and Weigel, R. M. (2006): Comparison of API 20E and invA PCR for identification of Salmonella enterica isolates from swine production units. J. Clin. Microbiol. 44(9): 3388-3390.

O'Brien T.F. (2002): Emergence, spread, and environmental effect of antimicrobial resistance: how use of an antimicrobial anywhere can increase resistance to any antimicrobial anywhere else. Clinical Infectious Diseases, 34: 78-84.

Oliveria, S. D.; Rodenbusch, C. R.; Ce', M. C.; Rocha, S. L. S. and Canal C. W. (2003): Evaluation of selective and nonselective enrichment PCR Procedures for Salmonella detection. Letters in Applied Microbiology. 36, : 217-221.

Olsen, S. J.; Bishop, R.; Brenner, F. W.; Roels, T. H.; Bean, N.; Tauxe, R. V. \& Slutsker, L. (2001): The changing epidemiology of Salmonella: trends in serotypes isolated from humans in the United States, 1987-1997. J Infect Dis, 183, 753-61. 
Postollec, F.; Falentin, H.; Pavan, S.; Combrisson, J.; Sohier, D. (2011): Recent advances in quantitative PCR (qPCR) applications in food microbiology. Food Microbiol 28(5):848-861

Randa, F. L. (2006): Bacteriological and serological studies on Salmonellae in pigs. M. v. sc. Thesis Bacterology, Mycology and Immunology, Vet. Med. Beni Suef University.

Saeed, A. A.; Hasoon, F. and Majed, H. (2011): Isolation and Molecular Identification of Salmonella typhimurium from Chicken Meat in Iraq. J. World's Poult. Res. 3(2): 63-67.

Sambrook, J.; Fritsch. E. T and Maniates, T. (1989): Molecular cloning a laboratory manual second edition. Cold Spring Harbry Laboratory Press, Cold Spring Harbor; New York.

Scallan, E.; Hoekstra, R.M.; Angulo, F.j.; Tauxe, R.V.; Widdowson, M.A.; Roy, S.L.; Jones, J.L.; Griffin, P.M. (2011): . Foodborne illness acquired in the United States-major pathogens. Emerg. Infect. Dis. 17:7-15.

Soumet, C.; Ermel, G.; Rose, V.; Drouin, P.; Salvat, G. and Colin,
P. (1999): Identification by a multiplex PCR based assay of Salmonella typhimurium and Salmonella enteritidis strains from environmental swabs of poultry houses. Lett. Appli. Microbiol., 29:1-6.

Soto, M.; Gonza-Havia, M. A. and Mendoza, M. C. (2003): Antimicrobial resistance in clinical isolates of Salmonella enterica serotype enteritidis: developed the relationships between mutations conferring quinolone resistance, integrons, plasmids and genetic types. Journal of Antimicrobial Chemotherapy, 51: 1287-1291.

Sultana, K.; Bushra, M. A. and Nafisa, I. (1995): Evaluation of antibiotic resistance in clinical isolates of Salmonella typhi from Islamabad, Pakistan. Zoology, 27:185-187.

White, P.; Meglli, K.; Collins, D.; and Gormely, E. (2002): The prevalence and PCR detection of Salmonella contamination in raw poultry. Vet. Microbiol. 89: 53-60. WHO (2003): World Health organization. Department of communicable diseases surveillance and response. 